\title{
Common Structural Details and Deficiencies in Indonesian RC Buildings: Preliminary Report on Field Investigation in Padang City, West Sumatra
}

\author{
Syafri Wardi ${ }^{\#+}$, Yasushi Sanada ${ }^{\#}$, Michihiro Kita ${ }^{\#}$, Jafril Tanjung ${ }^{*}$, Maidiawati ${ }^{+}$ \\ ${ }^{\#}$ Architectural Engineering Department, Osaka University, Suita, 565-0871, Japan \\ E-mail: wardi_safri@arch.eng.osaka-u.ac.jp,sanada@arch.eng.osaka-u.ac.jp,kita@arch.eng.osaka-u.ac.jp \\ ${ }^{*}$ Civil Engineering Department, Andalas University, Padang, 25163, Indonesia \\ E-mail: jafriltanjung@ft.unand.ac.id \\ ${ }^{+}$Civil Engineering Department, Padang Institute of Technology, Padang, 25143, Indonesia \\ E-mail: maidiawati@yahoo.com
}

\begin{abstract}
Significant damage to reinforced concrete buildings by the 2009 Western Sumatera Earthquake revealed that deficiencies in design engineering and/or construction practice existed. This indicated that enforcement of building design codes was lacking. The Indonesian government has updated the building design codes which should have been applied in the construction of new buildings. However, enforcement of these codes on design engineering and/or construction practice in Padang city is not clear. In this study, a field investigation was performed to investigate common structural details and deficiencies in newly constructed multi-story reinforced concrete buildings. The investigation was conducted through visiting building construction sites in Padang city area. This study preliminary reports the investigation results on 39 private buildings and 8 government buildings. The common deficiencies found on the investigated buildings were low material quality, small structural dimensions with light longitudinal reinforcement, insufficient transverse reinforcement with poor details, improper location of lap splice of rebar, lack of hoops inside exterior and interior beam-column joints, and deficient anchorage of beam reinforcement to exterior beam-column joints. These investigation results clarify that enforcement of the latest buildings design codes in design engineering and/or construction practice is still lacking in the investigated area.
\end{abstract}

Keywords — beam-column joint; deficiency; Indonesia; onsite investigation; reinforced concrete

\section{INTRODUCTION}

The 7.6 Mw Western Sumatera-Indonesia earthquake had caused significant damage to many reinforced concrete (RC) buildings, including both older and newer buildings. Examples of collapsed multi-story RC buildings in Padang city are shown in Fig. 1. This indicated that enforcement of building codes on buildings built prior to 2009 was lacking in Padang which resulted in deficiencies in design engineering and/or construction practice.

Deficiencies observed on collapsed/damaged buildings after the 2009 earthquake were similar to those seen in older $\mathrm{RC}$ buildings in the US and developing regions throughout the world, such as low material quality, use of plain reinforcing bars, insufficient column ties with 90 degree hooks with minimal overlap, and absence of column stirrups in beam-column joint. Concrete frame member sizes smaller than required to resist ground motion demands were also found on such older buildings [1]. These kinds of deficiencies may exist in recently constructed buildings in Indonesia.

In 2012, Indonesian seismic design code was updated to SNI 1726:2012 [2]. Indonesian concrete design code for buildings also has been updated to SNI 2847:2013 [3] in 2013. These codes have regulated higher seismic base shear and the more stringent detailing requirement for $\mathrm{RC}$ buildings, especially for those built in the high seismic risk area. RC buildings built recently should comply with the requirements of these latest design codes to prevent significant damage to buildings against future earthquakes.

In this study, a field investigation was conducted to inspect common structural details and deficiencies in newly constructed multi-story RC buildings in Padang. The investigation result can clarify the enforcement of latest building design codes on design engineering and/or construction practice. 
Past studies by some authors (e.g. [4]-[9]) have focused on buildings damaged by recent earthquakes in developing countries. Restoration and retrofitting of RC buildings also have been popular topics, as investigated by many researchers (e.g. [10], [11]). However, very few attempts were made to investigate the deficiencies of newly constructed buildings.

\section{MATERIAL AND METHOD}

Field investigation has been conducted to collect the statistical data of common structural details and deficiencies of the buildings.

\section{A. Location of Investigation}

The investigation was conducted within the area of Padang city. Padang city is the capital city of West Sumatera Province which has an area of $695 \mathrm{~km}^{2}$ and the population of 902,413 in 2015 [12]. The city is divided into 11 districts, as shown in Fig. 2. The downtown area is close to coast and consist of 5 districts: Padang Utara, Padang Selatan, Padang Barat, Padang Timur, and Nanggalo. The downtown area is utilized as a centre of governmental and commercial activities:
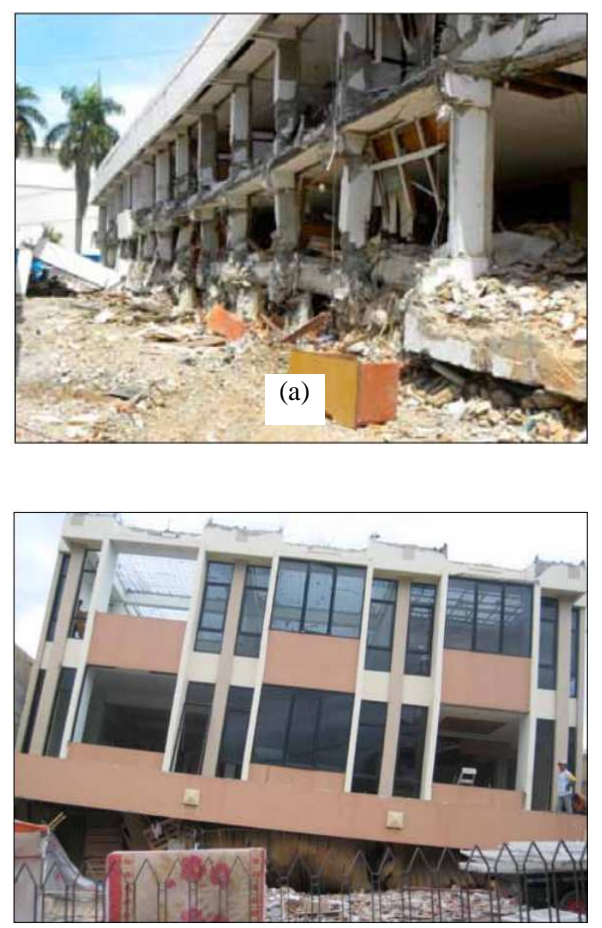

(b)

Fig. 1 Example of collapsed buildings; (a) A collapsed 3-story government building; (b) First story failure of a 3-story shop-house [1]

\section{B. The scope of Investigated Buildings}

The investigation was conducted on multi-story RC buildings which were under construction within a period of September 2016 to March 2017. RC buildings in Padang can be divided into two categories:

1) $\mathrm{RC}$ frame with infill masonry buildings which rely on $\mathrm{RC}$ columns and beams as the main load bearing structural elements. RC frame is constructed first, and masonry walls are constructed at a later stage as non-structural walls. This system is usually applied to buildings with two-story or more.

2) Confined masonry buildings which rely on masonry walls as the main load bearing structural elements. Masonry walls are constructed first, and tie-columns and tie-beams are constructed subsequently as confinement. This system is usually applied to one or two-story building.

This study focuses only on RC frame with infill masonry buildings. Confined masonry buildings were excluded in the investigation.

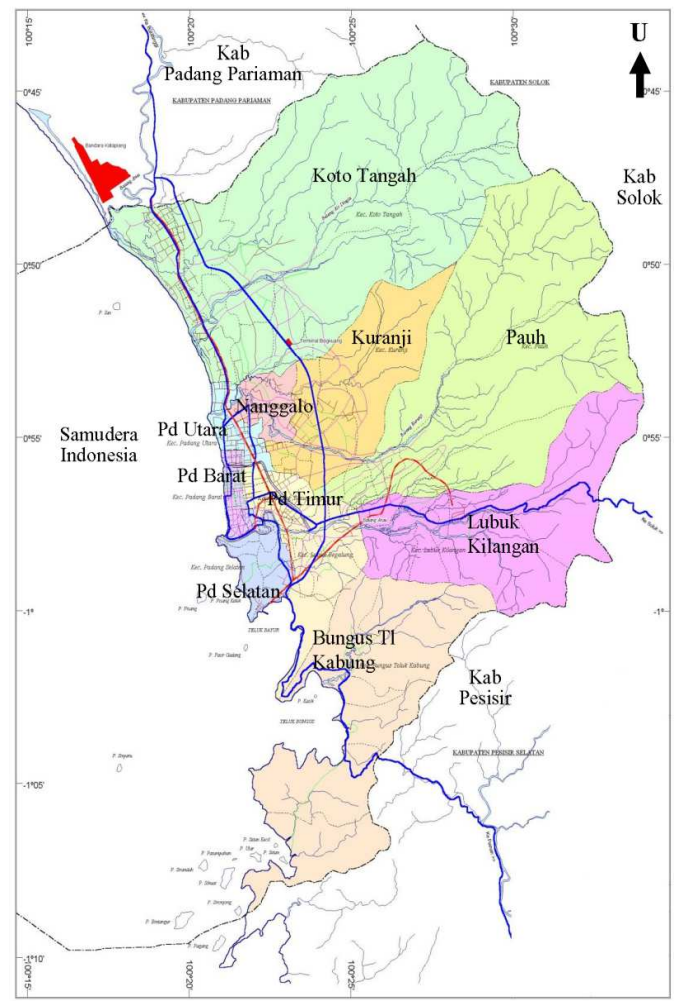

Fig. 2 Administrative map of Padang city [12]

\section{Investigation Items and Methods}

The investigation was carried out by visiting building construction sites. Building data were obtained by on-site inspection and/or design drawing. Material specification, detailing of column, beam, and beam-column joint were focused on the investigation. Table 1 shows the list of investigated items and methods to obtain the data.

\section{Evaluation Methods}

The investigated items were evaluated by comparing the data obtained from real construction with the requirements of Indonesian design codes. Based on the Indonesian seismic design code SNI 1726:2012 [2], Padang city is located in seismic design category of D. RC frame buildings built in this area should be designed as special moment resisting frame (SMRF).

$\mathrm{RC}$ frame with infill masonry buildings is commonly designed as open moment resisting frame in design. Masonry infill walls are regarded as a non-structural element of which the stiffness and strength are not typically considered in the design. Thus, RC frame with infill masonry buildings built in Padang city should meet the requirements for concrete SMRF, as regulated in the Indonesian concrete design code SNI 2847:2013 [3]. 
TABLE I

LIST OF INVESTIGATED ITEMS AND METHODS

\begin{tabular}{|c|c|c|}
\hline \multicolumn{2}{|c|}{ Investigated items } & Methods \\
\hline \multirow[t]{2}{*}{$\begin{array}{l}\text { Material } \\
\text { specification }\end{array}$} & $\begin{array}{l}\text { The compressive } \\
\text { strength of concrete }\end{array}$ & $\begin{array}{l}\text { - Design drawing } \\
\text { - Hammer test*1 }\end{array}$ \\
\hline & Type of rebar & \multirow{4}{*}{$\begin{array}{l}\text { - Design drawing and } \\
\text { field inspection } *^{2}\end{array}$} \\
\hline \multirow{4}{*}{$\begin{array}{l}\text { Detailing of } \\
\text { column }\end{array}$} & Dimension & \\
\hline & $\begin{array}{l}\text { Longitudinal } \\
\text { reinforcement }\end{array}$ & \\
\hline & $\begin{array}{l}\text { Transverse } \\
\text { reinforcement }\end{array}$ & \\
\hline & Lap splice & - Field inspection $*^{3}$ \\
\hline \multirow{4}{*}{$\begin{array}{l}\text { Detailing of } \\
\text { beam }\end{array}$} & Dimension & \multirow{3}{*}{$\begin{array}{l}\text { - Design drawing and } \\
\text { field inspection*2 }\end{array}$} \\
\hline & $\begin{array}{l}\text { Longitudinal } \\
\text { reinforcement }\end{array}$ & \\
\hline & $\begin{array}{l}\text { Transverse } \\
\text { reinforcement }\end{array}$ & \\
\hline & Lap splice & - Field inspection $*^{3}$ \\
\hline \multirow{2}{*}{$\begin{array}{l}\text { Detailing of } \\
\text { beam-column } \\
\text { joint }\end{array}$} & $\begin{array}{l}\text { Transverse } \\
\text { reinforcement in joint }\end{array}$ & \multirow{2}{*}{ - Field inspection $*^{3}$} \\
\hline & $\begin{array}{l}\text { Anchorage of beam } \\
\text { reinforcement }\end{array}$ & \\
\hline
\end{tabular}

$*^{1}$ Hammer test was used to estimate the compressive strength of concrete if it could not be obtained from design drawing.

$*^{2}$ Detailing of these items is commonly provided in the design drawing. Then, the data were confirmed through field inspection.

$*^{3}$ Detailing of these items is not commonly provided clearly in the design drawing. The data were obtained by field inspection

\section{E. Number of Investigated Buildings}

This study investigated 47 buildings which consist of 8 government buildings and 39 private buildings. A number of the investigated buildings at every district in Padang city is shown in Fig. 3.

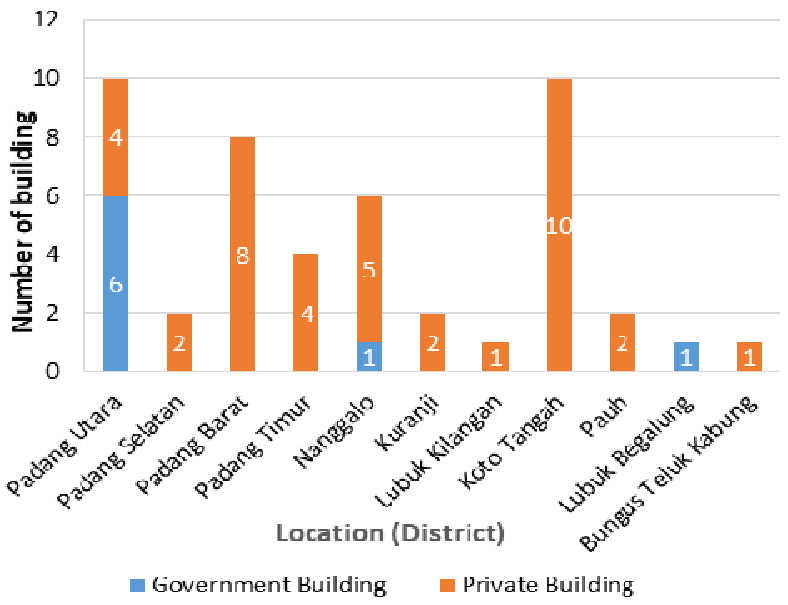

Fig. 3 Number of investigated buildings in each district

The distributions of the number of stories and category of function are shown in Fig. 4 and Fig. 5, respectively.

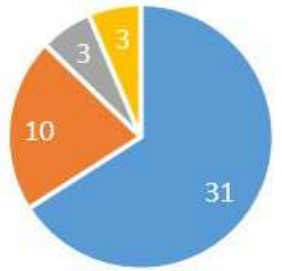

= 2 storey $=3$ storey $=4$ storey $=>4$ storey

Fig. 4 Distribution of number of stories of buildings

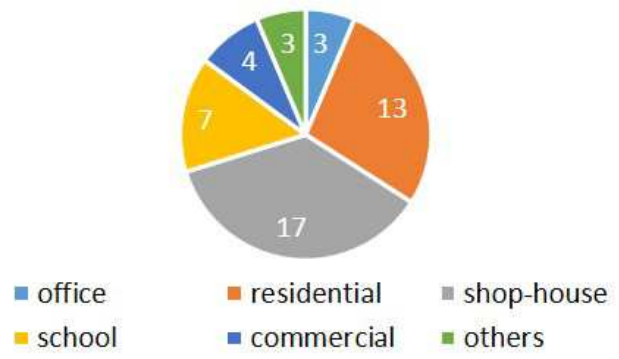

Fig. 5 Distribution of category of the function of buildings

\section{RESULTS AND DISCUSSION}

The results of field investigation were divided into four sections: material specification, detailing of the column, beam, and beam-column joint.

\section{A. Material Specifications}

1) Concrete Material: For $\mathrm{RC}$ buildings in the high seismic risk area, the Indonesian concrete design code [3] has provisioned the minimum concrete compressive strength (fc') to be $20 \mathrm{MPa}$. However, eight private buildings (20\%) did not meet this requirement, as shown in Fig. 6. These buildings applied concrete with the standard of K-225 (cubical compressive strength of $225 \mathrm{~kg} / \mathrm{cm} 2$ ) which corresponded to cylindrical compressive strength (fc') of 18 $\mathrm{MPa}$.

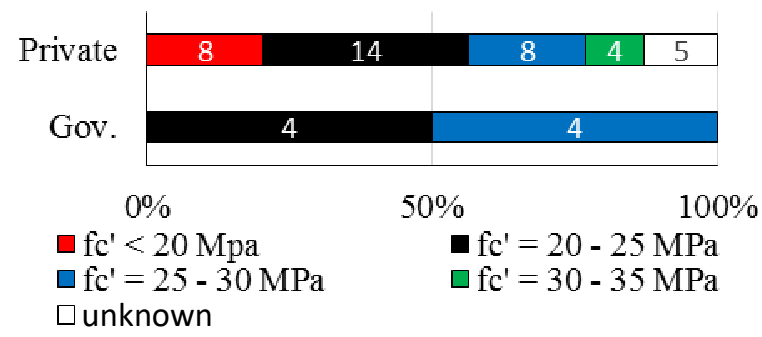

Fig. 6 Investigation results in concrete compressive strength

2) Rebar Material: The Indonesian concrete design code [3] has regulated that deformed bar should be used as reinforcement. The plain bar is allowed to use only for spiral reinforcement. However, thirteen private buildings (33\%) applied plain rebar for longitudinal reinforcement, as shown in Fig. 7(a). Furthermore, thirty five private buildings $(90 \%)$ and five government buildings (62\%) applied plain rebar for transverse reinforcement, as shown in Fig. 7(b). Plain rebar is not recommended especially for flexural reinforcement because it has very low bonding without mechanical interlocking with concrete.

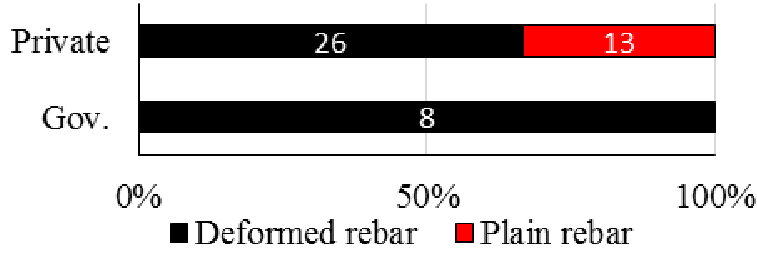

(a) 


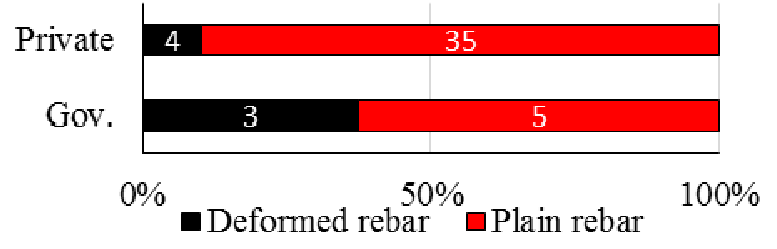

(b)

Fig. 7 Investigation results on types of rebar used as reinforcement; (a) Longitudinal reinforcement; (b) Transverse reinforcement

\section{B. Detailing of Column}

1) Dimensions of Column: Column with too small dimensions can lead to "weak column-strong beam" mechanism which may cause story collapse of buildings. The Indonesian code [3] regulates that the shortest crosssectional dimensions of column shall be not less than 300 $\mathrm{mm}$ and the ratio of the shortest cross-sectional dimension to perpendicular dimension shall be not less than 0.4. However, thirteen private buildings $(33 \%)$ did not meet the requirement for the minimum cross-sectional dimensions and three private buildings (8\%) did not meet the requirement for the ratio of cross-sectional dimensions, as shown in Fig. 8(a) and 8(b).

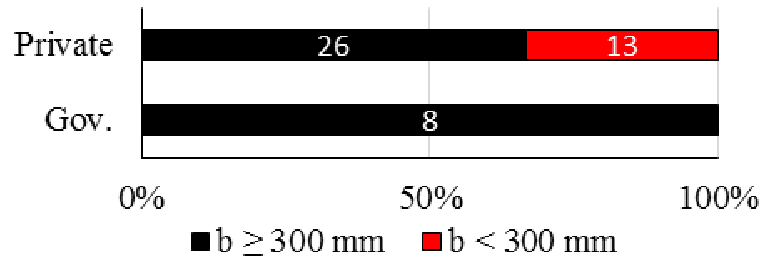

(a)

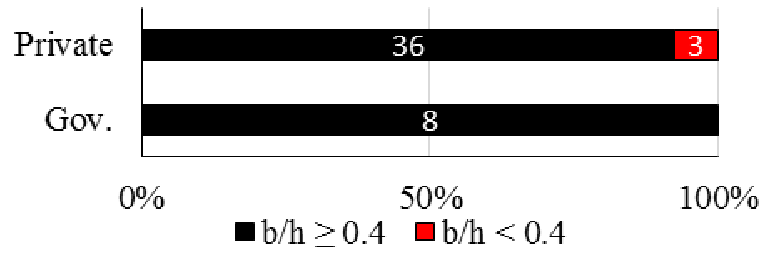

(b)

Fig. 8 Investigation results on cross-sectional dimensions of the column; (a) Minimum cross-sectional dimension; (b) Ratio of cross-sectional dimensions

2) Longitudinal Reinforcement in Column: According to the Indonesian code [3], the volumetric ratio of longitudinal reinforcement $(\rho)$ shall be not less than 0.01 and shall not exceed 0.06 . However, six private buildings (15\%) did not meet the requirement of the minimum reinforcement ratio, as shown in Fig. 9. Columns with longitudinal reinforcement less than the minimum have the potential of yielding resulting from creep deformations of concrete, which may lead to premature flexural failure of the columns.

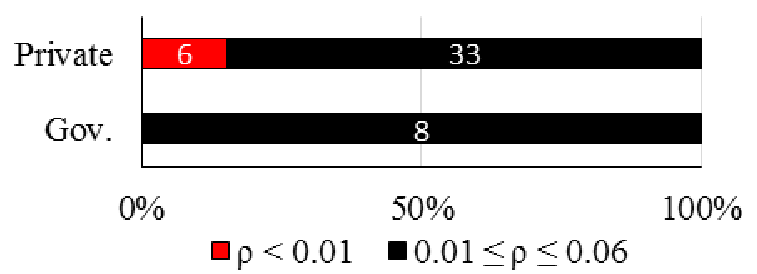

Fig. 9 Investigation results on the ratio of flexural reinforcement in column
3) Transverse Reinforcement in Column: Detailing of transverse reinforcement of column is very important. The transverse reinforcement is not only to resist the shear force, but also to give confinement effects on concrete. The Indonesian code [3] stipulates that the area of transverse reinforcement $\left(\mathrm{A}_{\mathrm{v}}\right)$ in the potential plastic hinge region shall not be less than values of $A_{s h}$ given by the following two equations:

$$
\begin{gathered}
A_{s h}=0.3\left(s_{c} f^{\prime} / / f_{y t}\right)\left[\left(A_{g} / A_{c h}\right)-1\right] \\
A_{s h}=0.09\left(s_{c} f_{c}{ }^{\prime} / f_{y t}\right)
\end{gathered}
$$

The symbols in Equations can be referred to Nomenclature. Fig. 10 shows that thirty six private buildings $(92 \%)$ and four government buildings $(50 \%)$ did not meet the requirement for the area of transverse reinforcement. Many of them lacked inner hoops (cross-ties).

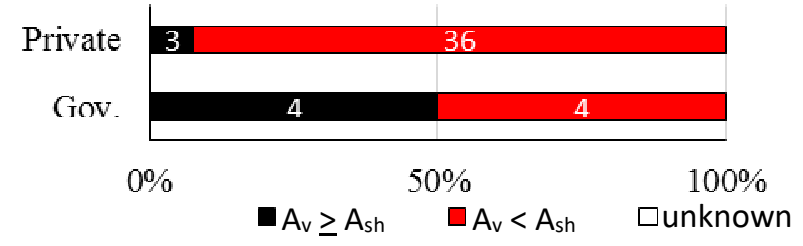

Fig. 10 Investigation results in the area of transverse reinforcement in column

Fig. 11 describes the requirements for the maximum spacing of transverse reinforcement in accordance with the Indonesian code [3]. The investigation results in Fig. 12(a) show that twenty eight private buildings (72\%) and two government buildings $(25 \%)$ did not meet the requirement for the spacing of transverse reinforcement in the hinge region. Moreover, thirty five private buildings (90\%) and four government buildings $(50 \%)$ did not meet the requirement for the spacing of transverse reinforcement in the non-hinge region, as shown in Fig. 12(b).

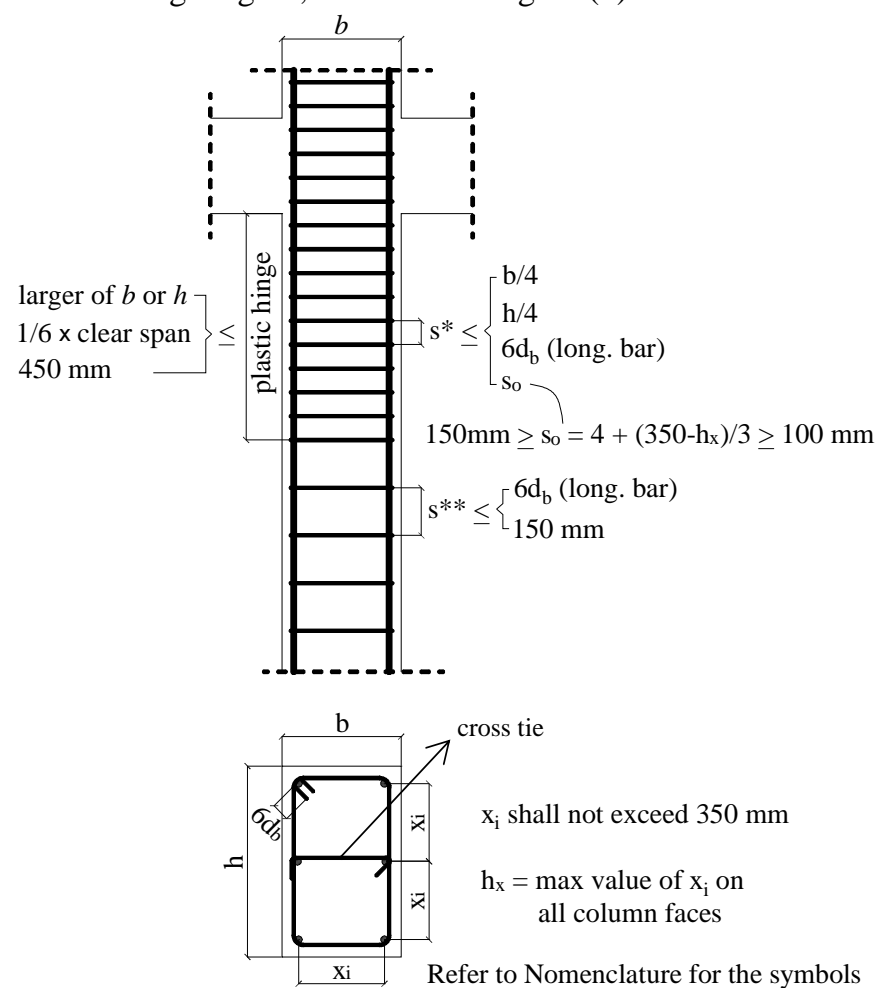

Fig. 11 Requirements for transverse reinforcement of column 


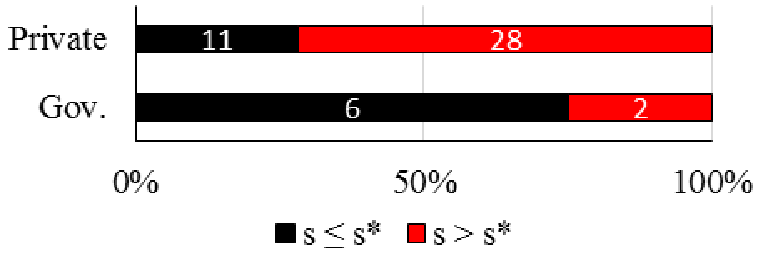

(a)

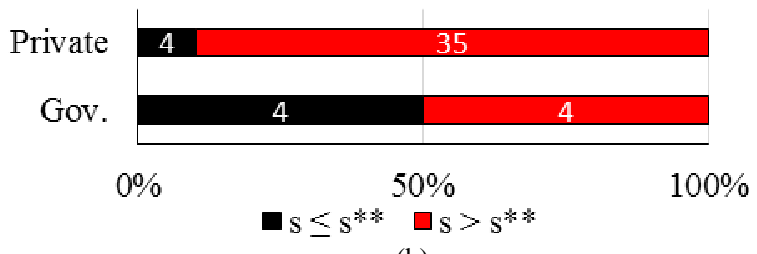

(b)

Fig. 12 Investigation results on the spacing of transverse reinforcement in the column; (a) Hinge region; (b) Non-hinge region

The Indonesian code [3] also stipulates application of seismic hooks with $135^{\circ}$ or more and the length not less than $6 \mathrm{~d}_{\mathrm{b}}$ (transverse bar) to column stirrups. However, in real construction, twenty two private buildings $(56 \%)$ and two government buildings $(25 \%)$ applied $90^{\circ}$ hooks, as shown in Fig. 13(a). Moreover, twelve private buildings (31\%) and one government building (12\%) applied hooks of column hoops with the length less than $6 d_{b}$, as shown in Fig. 13(b).

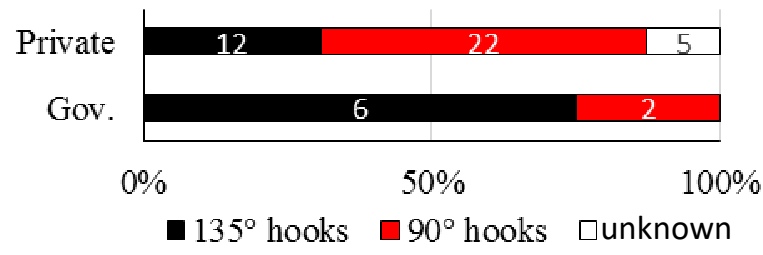

(a)

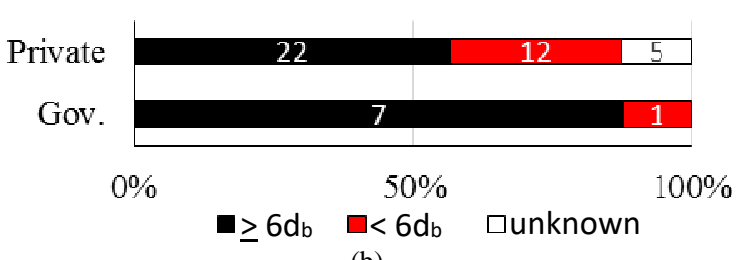

(b)

Fig. 13 Investigation results on details of seismic hooks of column stirrups; (a) Angle of hooks; (b) Length of hooks

4) Lap Splice in Column: The Indonesian code [3] regulates that no lap splice shall be used within the joint or within a distance of twice member depth from the face of joint (hinge area). However, twenty two private buildings (56\%) and seven government buildings (87\%) applied lap splices in this potential hinge area, as shown in Fig. 14(a). Moreover, the lap splice of column shall be designed as a tension splice; thus the length shall not be less than:

$$
\begin{aligned}
1_{d}=\frac{f_{y} d_{b}}{1.7 \sqrt{f_{c}^{\prime}}} & \text { for } d_{b} \geq 22 \mathrm{~mm} \\
1_{d}=\frac{f_{y} d_{b}}{2.1 \sqrt{f_{c}^{\prime}}} & \text { for } d_{b}<22 \mathrm{~mm}
\end{aligned}
$$

Fig. 14(b) shows that five private buildings (13\%) and six government buildings $(75 \%)$ did not meet the requirement for the length of lap splice. In many buildings, the length of lap splice was conventionally defined as $40 \mathrm{~d}_{\mathrm{b}}$ (longitudinal bar) which tends to give smaller length than Equation (3) or (4).

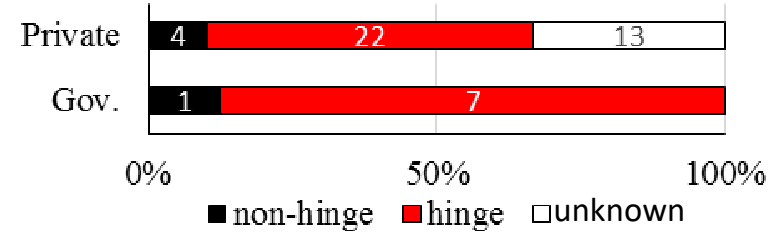

(a)

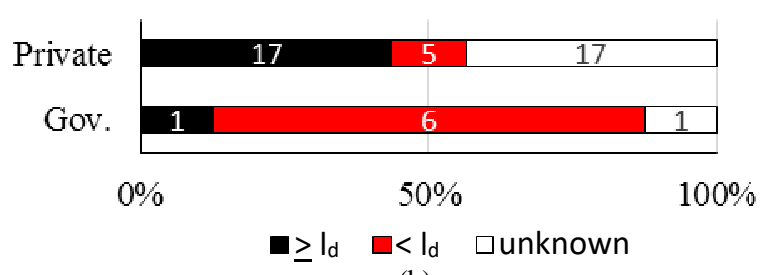

(b)

Fig. 14 Investigation results on lap splice in the column; (a) Location of splice; (b) Length of splice

\section{Detailing of Beam}

1) Dimensions of Beam: The Indonesian code [3] has provisioned that width of the beam shall be $\geq 250 \mathrm{~mm}$, and the ratio of width to depth shall be $\geq 0.3$. However, eleven private buildings (28\%) and one government building (12\%) did not meet the requirement for the minimum width, as shown in Fig. 15(a). Moreover, one private building (3\%) did not meet the requirement for the ratio of width to depth, as shown in Fig. 15(b).

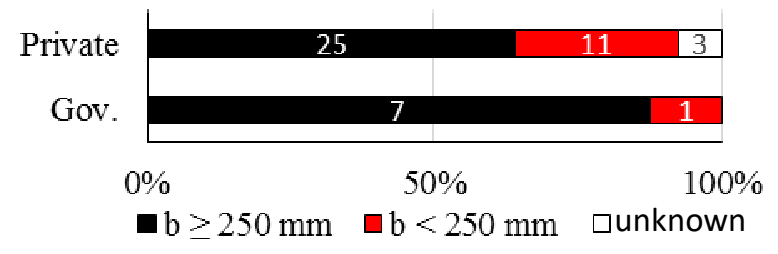

(a)

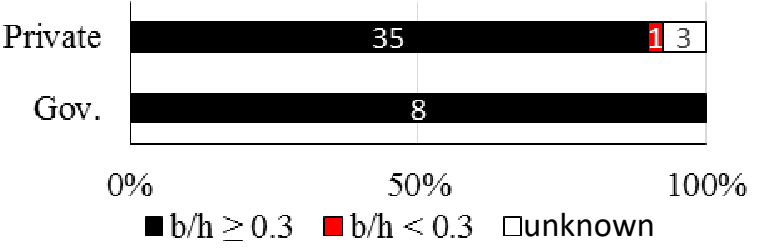

(b)

Fig. 15 Investigation results on cross-sectional dimensions of the beam; (a) Minimum width; (b) Ratio of width to depth

2) Longitudinal Reinforcement in Beam: According to the Indonesian code [3], the minimum area of tensile or compressive reinforcement in beam shall not be less than the maximum value obtained by Eq. 5 and Eq. 6, and the reinforcement ratio shall not exceed 0.025. However, seventeen private buildings $(43 \%)$ did not meet the requirement of the minimum reinforcement ratio, as shown in Fig. 16.

$$
\rho_{\min }=\frac{1.4 b_{w} d}{f_{y}}
$$




$$
\rho_{\min }=\frac{0.25 \sqrt{f_{c}^{\prime}}}{f_{y}} b_{w} d
$$

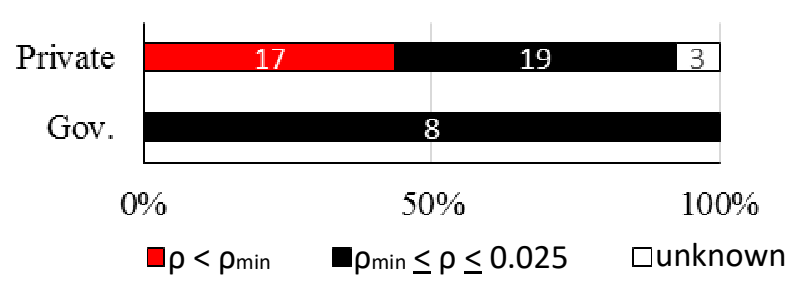

Fig. 16 Investigation results on the ratio of longitudinal reinforcement in the beam

3) Transverse Reinforcement in Beam: Requirements for the maximum spacing of transverse reinforcement in the beam in the Indonesian code [3] are described in Fig. 17. The investigation results in Fig. 18(a) shows that twenty five private buildings (64\%) and one government building (12\%) did not meet the requirement for the spacing of transverse reinforcement in the hinge region. Furthermore, seven private buildings (18\%) and one government building (12\%) did not meet the requirement for the spacing of transverse reinforcement in the non-hinge region, as shown in Fig. 18(b).

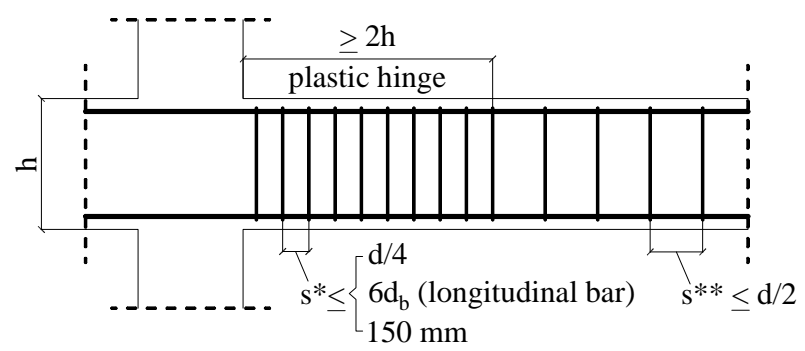

Fig. 17 Requirements for spacing of transverse reinforcement in the beam

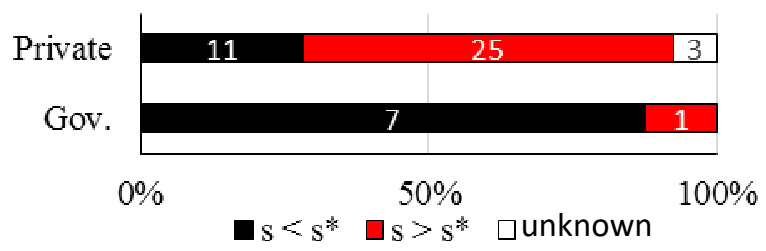

(a)

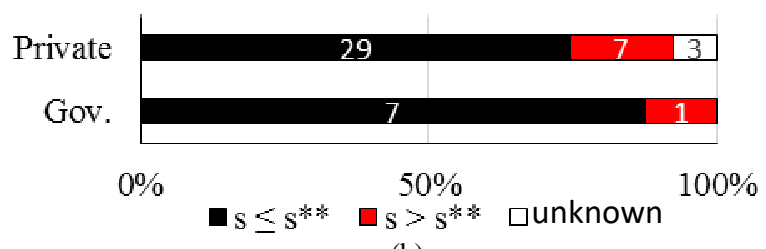

(b)

Fig. 18 Investigation results on the spacing of transverse reinforcement in the beam

Seismic hooks with $135^{\circ}$ or more and the length not less than $6 d_{b}$ (transverse bar) shall be applied to beam hoops. However, in real construction, twenty seven private buildings $(69 \%)$ and three government buildings (37\%) applied $90^{\circ}$ hooks, as shown in Fig. 19(a). Moreover, twelve private buildings $(31 \%)$ and three government buildings (37\%) had the length of hooks of stirrups less than $6 d_{b}$, as shown in Fig. 19(b).

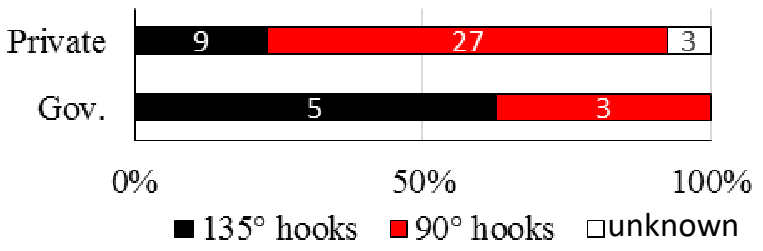

(a)

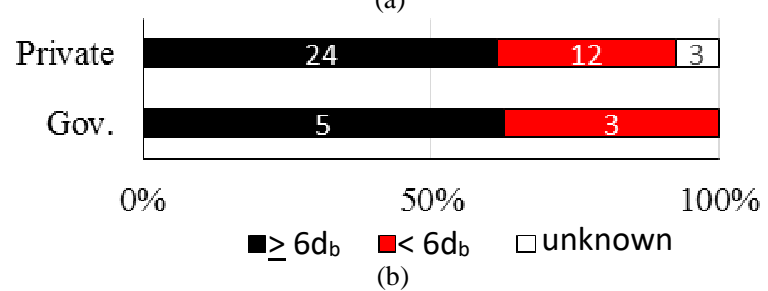

Fig. 19 Investigation results on details of seismic hooks of beam stirrups

4) Lap Splice in Beam: The provisions for lap splices in the beam are similar to those on the column as explained in Section III.B.4. The investigation results in Fig. 20(a) shows that twenty private buildings $(51 \%)$ and six government buildings $(75 \%)$ applied lap splices in the hinge region. Fig. 20(b) shows that seven private buildings (18\%) and seven government buildings (87\%) had lap splices with lengths less than the required length $\left(l_{d}\right)$. In many buildings, the length of lap splice in the beam was conventionally defined as $40 \mathrm{~d}_{\mathrm{b}}$ (longitudinal bar) which tends to give smaller lengths than required by the latest code [3].

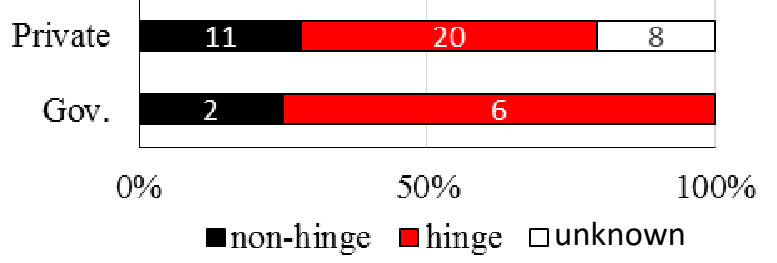

(a)

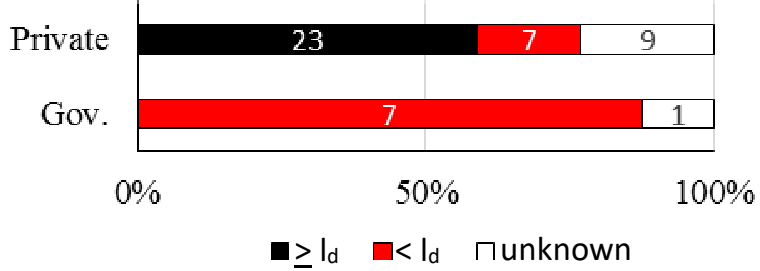

(b)

Fig. 20 Investigation results on lap splice in the beam; (a) Location of splice; (b) Length of splice

\section{Detailing of Beam-Column Joint}

1) Transverse Reinforcement in Joint: The Indonesian concrete design code [3] has provisioned that transverse reinforcement should be provided inside beam-column joints. For an exterior joint, amount and spacing of the transverse reinforcement are similar for those on the adjacent column hinge region which was explained in Section III.B.3. For an interior joint, if the beam width is at least $3 / 4$ of the column width, the transverse reinforcement can be reduced to $50 \%$, while its spacing shall not exceed $150 \mathrm{~mm}$.

Fig. 21(a) shows the investigation result of hoop details in the exterior beam-column joints. Most of the investigated buildings did not satisfy the requirements for hoops in the exterior joint. For private buildings, twenty three cases $(59 \%)$ contained no hoops in the exterior joints, while nine 
cases $(23 \%)$ contained hoops less than the requirements. For government buildings, five cases $(62 \%)$ contained hoops less than the requirements, while two buildings (25\%) contained no hoops.

Fig. 21(b) shows the investigation result of hoop details in the interior beam-column joints. Only three private buildings $(8 \%)$ and two government buildings (25\%) satisfied the requirements for hoops inside the interior joint. Other buildings contained no hoops or insufficient hoops to the interior joints. In construction practice, hoops in the exterior and interior joint were likely not to be applied or reduced to eliminate difficulties posed by rebar congestion.

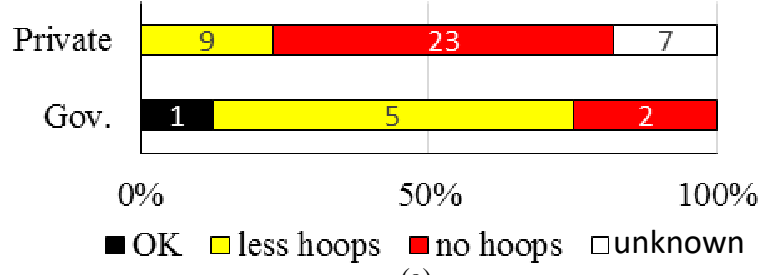

(a)

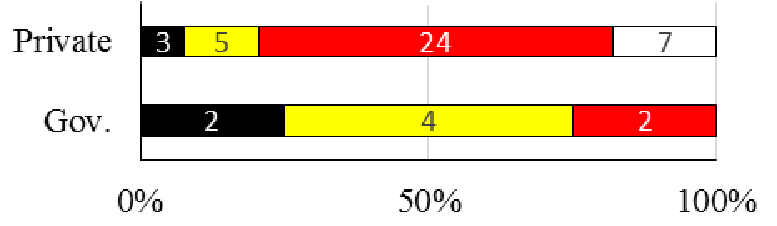

口OK $\square$ less hoops $\square$ no hoops $\square$ unknown

(b)

Fig. 21 Investigation results on hoops in beam-column joint; (a) Exterior joint; (b) Interior joint

2) Anchorage of Beam Reinforcement: The Indonesian code [3] regarding exterior joints stipulates that the longitudinal beam reinforcement in a column shall be extended to the far face of the confined column core and anchored. The length of anchorage $\left(1_{\mathrm{dh}}\right)$ shall be the largest of 8 bar diameters, $150 \mathrm{~mm}$, and the length required by the following equation:

$$
l_{\mathrm{dh}}=\frac{\mathrm{f}_{\mathrm{y}} \mathrm{d}_{\mathrm{b}}}{5.4 \sqrt{\mathrm{f}_{\mathrm{c}}^{\prime}}}
$$

The end of rebar should be bent with a $90^{\circ}$ hook, and the length of tail extension $\left(l_{\text {ext }}\right)$ shall not be less than $12 d_{b}$ (longitudinal bar). Many of the investigated buildings satisfied the requirement for the length of anchorage $\left(1_{\mathrm{dh}}\right)$, as shown in Fig. 22(a). However, many did not satisfy the requirement for the length of tail extension $\left(1_{\text {ext }}\right)$. Fig. 22(b) shows that twenty four private buildings $(61 \%)$ and five government buildings $(62 \%)$ had the length of tail extension $\left(l_{\text {ext }}\right)$ less than $12 d_{b}$.

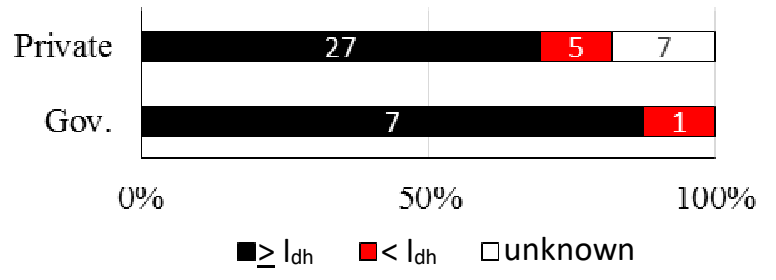

(a)

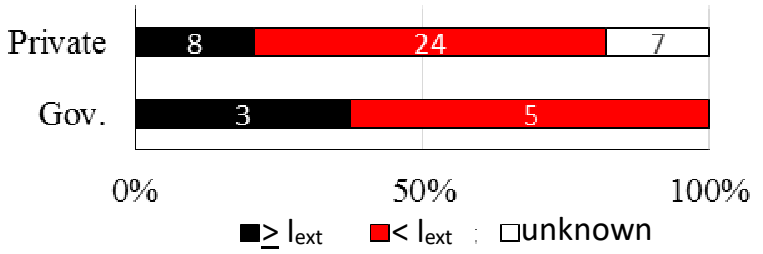

(b)

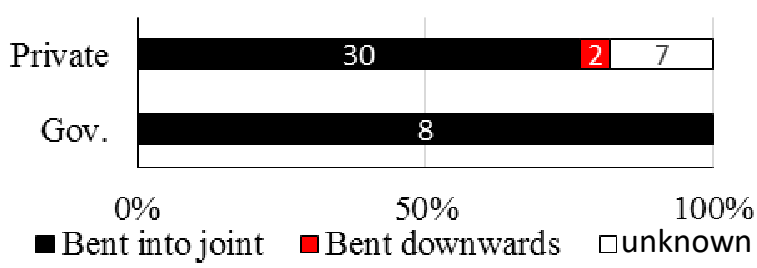

(c)

Fig. 22 Investigation results on hoops in beam-column joint; (a) Length of anchorage; (b) Length of tail extension; (c) Type of anchorage

The types of anchorage applied to the investigated buildings are shown in Fig. 22(c). It is widely known that the hooks should be bent into the joint (Fig. 23(a)). However, in two private buildings (5\%), both top and bottom beam longitudinal reinforcements were bent downwards (Fig. 23(b)).

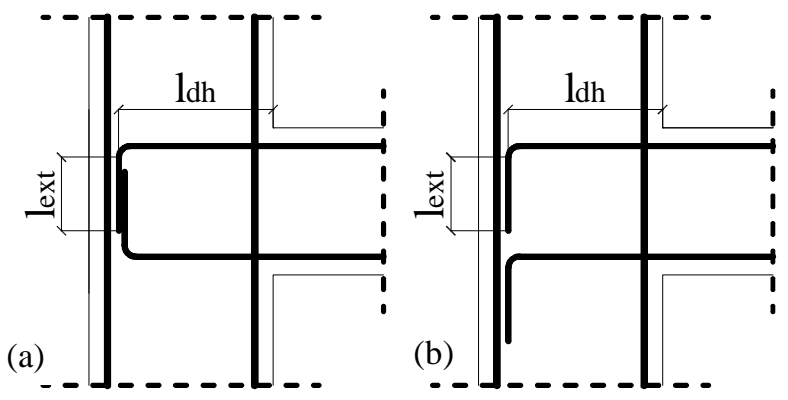

Fig. 23 Type of anchorage of beam rebar in exterior beam-column joint; (a) Bent into joint; (b) Bent downwards

Fig. 24 shows typical deficiencies observed in exterior beam-column joints in which shorter tail extensions $\left(l_{\text {ext }}\right)$ are applied to anchor beam reinforcement and no hoop is applied.

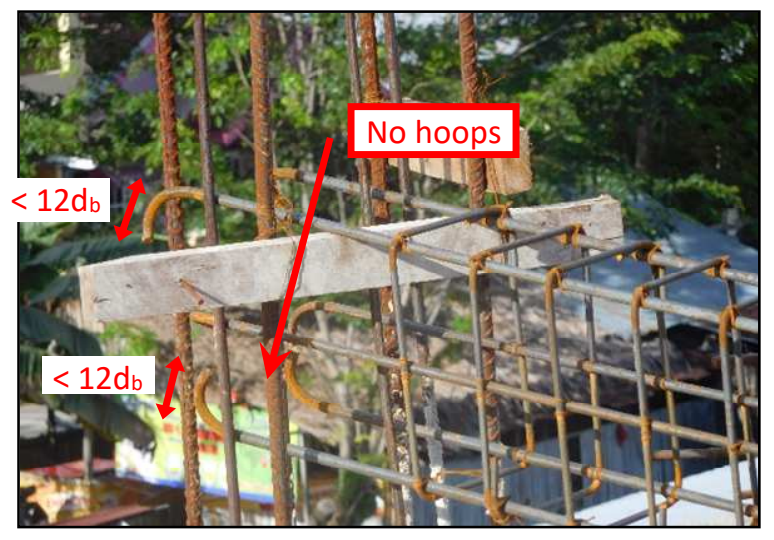

Fig. 24 Typical deficiencies in exterior beam-column joint

\section{CONCLUSIONS}

From the results of field investigation explained above, the common types of deficiencies found on RC buildings in the investigated area were as follows: 
1. Low material quality: i.e., low concrete compression strength and application of plain rebar.

2. A small column or beam dimensions with light longitudinal reinforcement.

3. Insufficient transverse reinforcement: i.e., lack of hoops in the column and large spacing between transverse reinforcements in column or beam.

4. Transverse reinforcement with a $90^{\circ}$ hook in column or beam.

5. Lap splice of rebar in hinge region in column or beam with an insufficient length of the splice.

6. Insufficient hoops or no hoops in exterior and interior beam-column joints.

7. Deficient anchorage of beam reinforcement to exterior beam-column joint.

These deficiencies reveal that enforcement of the latest building codes on design engineering and/or construction practice is still lacking in Padang city. The results of field investigation also show that government buildings have better structural details compared to private buildings.

\section{NOMENCLATURE}

$\mathrm{A}_{\mathrm{ch}} \quad$ cross-sectional area of a structural member measured to the outside edges of transverse reinforcement

$\mathrm{A}_{\mathrm{g}} \quad$ gross area of concrete section $\mathrm{mm}^{2}$

$A_{v} \quad$ total area of transverse reinforcement

$\mathrm{mm}^{2}$

$b, b_{w}$ width of member

$\mathrm{mm}^{2}$

$b_{c} \quad$ core dimension of column measured between outside edges of the transverse reinforcement in the direction concerned $\mathrm{mm}$

d effective depth of member

$\mathrm{mm}$

$\mathrm{d}_{\mathrm{b}} \quad$ diameter of rebar

$\mathrm{mm}$

fc' compressive strength of concrete

$\mathrm{MPa}$

$f_{y} \quad$ yield strength of longitudinal reinforcement

$\mathrm{MPa}$

$\mathrm{f}_{\mathrm{yt}} \quad$ yield strength of transverse reinforcement

$\mathrm{MPa}$

depth of member

$\mathrm{mm}$

length of lap splice

length of anchorage

length of tail extension

spacing of transverse reinforcement

spacing of transverse reinforcement in hinge region

$\mathrm{s} * * \quad$ spacing of transverse reinforcement in non-hinge region

$\rho \quad$ ratio of longitudinal reinforcement

$\rho_{\text {min }} \quad$ minimum ratio of longitudinal reinforcement $\mathrm{mm}$

$\mathrm{mm}$

no dimension no dimension

\section{ACKNOWLEDGMENT}

This study was supported by JSPS KAKENHI Grant Number 16H05650. We would like to thank Government of West Sumatera Province for the support during the field investigation.

\section{REFERENCES}

[1] EERI, Earthquake Engineering Research Institute, "Learning from earthquakes the Mw 7.6 Western Sumatra Earthquake of September 30, 2009," EERI Special Earthquake Report, pp. 1-12, 2009.

[2] Design Procedure of Earthquake Resistance for Buildings and Other Structures, National Standardization Agency of Indonesia, SNI 1726:2012, 2012.

[3] Requirements for Structural Concrete for Buildings, National Standardization Agency of Indonesia, SNI 2847:2013, 2013.

[4] H. Choi, Y. Nakano, Y. Sanada, H. Kuramoto, T. Tomonaga, Maidiawati, Y. Hayati and J. Tanjung, "Analytical Estimation of Seismic Response of a Typical R/C Building Damaged by the 2009 West Sumatra Earthquake in Indonesia," in Proc. 15th World Conference on Earthquake Engineering, Sept. 2012.

[5] Maidiawati, Yasushi Sanada, and Jafril Tanjung, "Seismic Performance Evaluation of Earthquake-Damaged Buildings in Indonesia Affected by Brick Masonry Infill," Proceedings of the 16th Japan-Taiwan-Korea Joint Seminar on Earthquake Engineering for Building Structures, pp. 195-204, Sept. 2014.

[6] Tatsuo Narafu, Toyokazu Shimizu, Yasushi Sanada, Yukio Tamura, Noriyuki Mita, Susumu Takahashi, Hayato Nakamura and Atsuko Itsuki, "Lessons Learnt from Damage to Buildings by Bohol Earthquake and Typhoon Yolanda 2013 in the Philippines," Bulletin of IISEE, Vol. 49, pp. 39-61, Feb. 2015.

[7] Yasushi Sanada, Yuebing Li, and Koki Maekawa, "Seismic Performance Evaluation and Retrofit of an R/C Frame with Brittle Beam-Column Joint Damaged by the 2013 Bohol, Philippines Earthquake," in Proc. Response of Structures under Extreme Loading, pp. 455-462, June 2015.

[8] Dipendra Gautam, Krishna Kumar Bhetwal, Hugo Rodrigues, Pramod Neupane, and Yasushi Sanada, "Observed Damage Patterns on Buildings during 2015 Gorkha (Nepal) Earthquake," in Proc. 14th International Symposium on New Technology for Urban Safety of Mega Cities in Asia, Paper ID SN3-7, Oct. 2015.

[9] Dipendra Gautam, Hugo Rodrigues, Krishna Kumar Bhetwal, Pramod Neupane and Yasushi Sanada, "Common structural and construction deficiencies of Nepalese buildings," Innovative Infrastructure Solutions, Vol. 1, Issue 1, March 2016.

[10] Zaidir, Rendy Thamrin, and Erick Dalmantias, "Evaluation of PreCracked RC Beams with Sealant Injection Methods," International Journal on Advanced Science Engineering Information Technology, vol. 7 (2017) No.2, pp-380-386, 2017.

[11] M. Jasssam and M. Altaee, "Effect of CFRP Plate Location on Flexural Behavior of RC Beam Strengthened with CFRP Plate," International Journal on Advanced Science Engineering Information Technology, vol. 1 (2011) No.6, pp-592-596, 2017.

[12] BPS Kota Padang, Padang in Figures 2014, 2014. 